\title{
Creating human organs in chimaera pigs: an ethical source of immunocompatible organs?
}

Citation for published version (APA):

Shaw, D., Dondorp, W., Geijsen, N., \& de Wert, G. (2015). Creating human organs in chimaera pigs: an ethical source of immunocompatible organs? Journal of Medical Ethics, 41(12), 970-974. https://doi.org/10.1136/medethics-2014-102224

Document status and date:

Published: 01/12/2015

DOI:

10.1136/medethics-2014-102224

Document Version:

Publisher's PDF, also known as Version of record

Document license:

Taverne

Please check the document version of this publication:

- A submitted manuscript is the version of the article upon submission and before peer-review. There can be important differences between the submitted version and the official published version of record.

People interested in the research are advised to contact the author for the final version of the publication, or visit the DOI to the publisher's website.

- The final author version and the galley proof are versions of the publication after peer review.

- The final published version features the final layout of the paper including the volume, issue and page numbers.

Link to publication

\footnotetext{
General rights rights.

- You may freely distribute the URL identifying the publication in the public portal. please follow below link for the End User Agreement:

www.umlib.nl/taverne-license

Take down policy

If you believe that this document breaches copyright please contact us at:

repository@maastrichtuniversity.nl

providing details and we will investigate your claim.
}

Copyright and moral rights for the publications made accessible in the public portal are retained by the authors and/or other copyright owners and it is a condition of accessing publications that users recognise and abide by the legal requirements associated with these

- Users may download and print one copy of any publication from the public portal for the purpose of private study or research.

- You may not further distribute the material or use it for any profit-making activity or commercial gain

If the publication is distributed under the terms of Article $25 \mathrm{fa}$ of the Dutch Copyright Act, indicated by the "Taverne" license above, 


\title{
Creating human organs in chimaera pigs: an ethical source of immunocompatible organs?
}

\author{
David Shaw, ${ }^{1,2}$ Wybo Dondorp, ${ }^{1}$ Niels Geijsen, ${ }^{3}$ Guido de Wert ${ }^{1}$
}

\begin{abstract}
${ }^{1}$ Department of Health, Ethics and Society, Research School GROW, Maastricht University, Maastricht, The Netherlands

${ }^{2}$ Institute for Biomedical Ethics, University of Basel

${ }^{3}$ Hubrecht Institute and University Medical Center Utrecht and Utrecht University, Faculty of Veterinary Medicine, Utrecht, The Netherlands
\end{abstract}

\section{Correspondence to}

Dr David Shaw, Department of Health, Ethics and Society,

University of Maastricht,

Postbus 616, Maastricht 6200MD, The Netherlands; davidmartinshaw@gmail.com

Received 2 May 2014 Revised 5 September 2014 Accepted 9 October 2014 Published Online First

5 November 2014

\section{SLinked}

- http://dx.doi.org/10.1136/ medethics-2014-102377

\section{CrossMark}

$$
\begin{aligned}
& \text { To cite: Shaw D, } \\
& \text { Dondorp W, Geijsen N, } \\
& \text { et al. J Med Ethics }
\end{aligned}
$$$$
\text { 2015;41:970-974 }
$$

\section{ABSTRACT}

New techniques in regenerative medicine may soon enable the creation of human organs inside animals using induced pluripotent stem cells. This technology has the potential to solve the organ scarcity problem by providing a limitless source of personalised organs for transplantation, but also raises several ethical issues, particularly concerning animal welfare, the 'human features' problem and human dignity.

\section{INTRODUCTION}

Cutting-edge animal research suggests that it will soon be possible to grow human organs in animals using induced pluripotent stem cells (iPSCs). iPSCs derived from a patient who needs an organ can be injected into a developing embryo of a different species such as a pig, giving the resulting animal a human kidney or other organ that can then be transplanted into the patient. Organs from such cross-species chimaeras have the potential to solve the current organ scarcity problem, and to provide organs that will not trigger a host immune reaction. This article describes and analyses the potential of these new techniques in regenerative medicine, and the associated ethical issues.

\section{THE ORGAN SCARCITY PROBLEM}

Thousands of people die every year because there are not enough organs available to meet demand. In the UK alone, it is estimated that three people die every day while waiting for an organ. ${ }^{1}$ As well as the loss of life caused by the organ scarcity problem, patients waiting for organs have a reduced quality of life. Their suffering and in many cases their avoidable premature deaths also have a substantial negative effect on the quality of life of their families, making organ scarcity a significant societal problem. Despite various attempts in different countries to increase deceased donation rates via opt-out consent systems and incentives ${ }^{2}$ and the altruistic actions of those who are willing to donate organs while still alive, there appears to be little prospect of meeting the demand for organs without also creating them artificially (see table 1). Three main routes towards the creation of viable 'man-made' organs have been pursued in recent years: in vivo creation of organs via xenotransplantation from genetically modified animals, in vitro creation of 'lab-grown' organs and the construction of bionic, mechanical organs. All three of these avenues have hit substantial technical hurdles, although research to overcome these obstacles is ongoing. In this paper, we discuss the use of pluripotent stem cells to create human organs inside animals. This novel biotechnology potentially offers two important advantages: it would provide a new source of organs, and these organs would be unlikely to be rejected by the recipients' immune system. In addition, 'chimaera organs' are highly likely to circumvent the problem of zoonosis (generation of new cross-species viruses) posed by other forms of xenotransplantation.

\section{THE ROLE OF PLURIPOTENT STEM CELLS IN REGENERATIVE MEDICINE}

Pluripotent stem cells (PSCs) have two essential properties. They can be expanded indefinitely without loss of their developmental potential, a process called self-renewal, and they can specialise (differentiate) into any of the different cell types in the body. As such, PSCs are viewed as a promising cellular source for the replacement of cells, and organs that are lost due to trauma or disease. Since 2006, these remarkable cells have been generated in the lab as iPSCs through the reprogramming of somatic cells such as skin cells.

The ability to derive iPSCs from the patient's own skin cells enables the possibility of personalised regenerative therapies ${ }^{3-6}$ with minimal risk of tissue rejection. Several clinical trials using human iPSCs are currently underway: Takahashi's macular degeneration trial at the RIKEN Center for Developmental Biology in Wako, Japan will start in $2014,{ }^{7}$ and trials are in preparation in Japan to explore the use of iPSC-derived blood platelets. ${ }^{8-10}$ In both these applications, transplantation of a single PSC-derived cell type is sufficient for treatment of the disease. In many instances, however, pathology is the result of the loss of function of an entire organ in which multiple cell types coordinately function in an anatomically complicated manner. While PSCs have the intrinsic ability to form entire organs, doing so in a laboratory setting has been extremely challenging. Recapitulating the temporal and anatomical choreography that directs the formation of complex organs such as the heart or kidney appears to represent an almost impossible challenge. The use of chimaeras could provide a solution to this problem, as doing so would entail growing PSC-derived human organs in an in vivo system.

\section{CREATING CHIMAERA ORGANS}

Recently, the teams of Nakauchi and Okabe demonstrated in a series of ground-breaking experiments that interspecific chimaeras can be used to guide the generation of entire complex organs, such as the 
Table 1 Potential solutions to the organ scarcity problem

\begin{tabular}{|c|c|c|}
\hline Proposed solution & Advantages & (Possible) disadvantages \\
\hline Increase number of living donations & Minor increase in number of organs available & $\begin{array}{l}\text { Poses risk to donors; } \\
\text { Limited scope }\end{array}$ \\
\hline Opt-out consent to posthumous donation & Potential increase in number of organs available & May not reflect donors' wishes; not always effective \\
\hline Mandatory donation after death & Substantial increase in number of organs available & Seen as disrespecting the dead and their families \\
\hline $\begin{array}{l}\text { Ignore family veto of donation from registered } \\
\text { donor }\end{array}$ & $\begin{array}{l}\text { Respects wishes of would-be donors; increases availability } \\
\text { of organs }\end{array}$ & Impractical; disrespects families \\
\hline Various incentives (such as tax breaks for donors) & Potential increase in number of organs available & $\begin{array}{l}\text { Relatively untested; seen as removing altruistic } \\
\text { motive }\end{array}$ \\
\hline Donation after cardiac death & Increases pool of potential donors & Donors might not be fully brain dead in some cases \\
\hline Market in human organs ${ }^{1}$ & Increase in pool of donors & Justice concerns \\
\hline Organs from transgene pigs & Increase in pool of organs & Sacrifice of pigs/zoonoses \\
\hline Lab-grown organs & No donor required & Higher risk of rejection \\
\hline Bionic organs & No donor required & Higher risk of rejection \\
\hline Chimaera organs & Lower risk of rejection than any other option & Requires sacrifice of pigs or primates \\
\hline
\end{tabular}

thymus or pancreas, from PSCs. ${ }^{11} 12$ In these studies, the researchers injected rat pluripotent stem cells into mutant mouse blastocysts and demonstrated that these cells integrate with the murine embryo and contribute to the development of all tissues. ${ }^{13}$ Furthermore, at locations where the murine cells fail to form specific tissues or cell types due to the specific genetic mutation, the injected rat cells take over this process entirely and as a result, a rat organ forms inside the developing rat/mouse chimaera (see figure 1). These mutant mice would normally be born lacking a pancreas or thymus, but the injection of wild type rat PSCs allowed the development of rat organs in these chimaeras. In theory, interspecific hybrids can be used to generate any tissue or organ type, regardless of its complexity.

The obvious next step would be to explore whether this technology could also be applied to human PSCs. Matsunari and colleagues recently reported that blastocyst complementation of Pdx1-mutant pig embryos allows the development of an entirely donor-derived pancreas (from a different type of pig), ${ }^{14}$ demonstrating that the Pdx1 pig could be a suitable host for the generation of pancreas tissue. Using a larger recipient animal, such as the pig or non-human primates, the generation of patientspecific organs through a combination of PSC and interspecific hybrid technology is now widely regarded as a real possibility. ${ }^{15}$ Indeed, it was recently demonstrated that human pluripotent stem cells have the ability to form chimaeras when injected into a host murine blastocyst. ${ }^{16}$ One problem that is still to be overcome is the need to also 'humanise' the animal's vascular system in order to obtain organs that are indeed completely human in order to avoid any remaining risks of rejection and cross-species infections. This could potentially be achieved by applying a multigene blastocyst-complementation approach, in which essential developmental regulators of vascular and lymphatic development are mutated in concert with a mutation for the desired organ.

The biotechnology required to create chimaera organs may take several years to perfect, and it is possible that an unforeseen technical obstacle could prevent the use of this regenerative technique in humans. Nonetheless, it is possible that a new source of immunocompatible organs could be ready for clinical
Figure 1 Illustration of creation of rat pancreas in mouse.
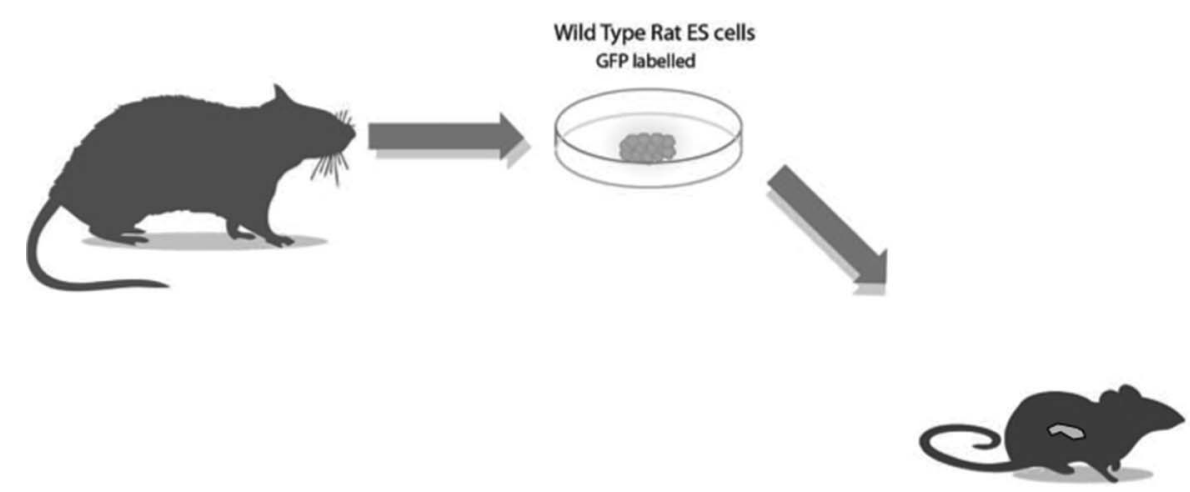

Rat pancreas in Pdx-/-mouse
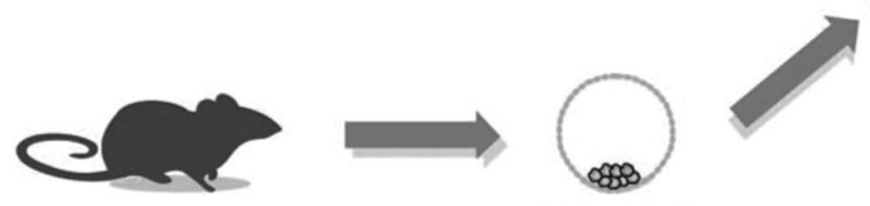

PDX1-/- embryo

(no pancreas) 
trials by the end of this decade. Therefore, the ethical issues raised by this fledgling biotechnology deserve consideration. However, it should be borne in mind throughout our discussion that research in this area is ongoing, and that considerable uncertainty surrounds the benefits and particularly the potential risks of chimaera organs. For the purposes of discussion here, we focus on the use of pigs to create chimaera organs, as pigs are regarded as the most scientifically promising source animal. Using primates for this purpose raises particularly challenging issues which we discuss elsewhere. ${ }^{17}$

\section{ADVANTAGES OF USING CHIMAERA ORGANS FOR TRANSPLANTATION}

\section{A new source of organs}

The most obvious advantage of chimaera organs is that they would provide an inexhaustible source of organs for transplantation. Anyone in need of a new organ could provide iPSCs which would be inserted in a pig embryo prior to implantation and gestation (see box 1). After around 6 months, the resulting pig would be sacrificed and the human organ removed and implanted in the original donor. Hundreds of thousands of lives would be saved every year if this technique was widely adopted, and many more people would have their quality of life improved if chimaera organs removed the need for dialysis.

\section{Lower risk of organ rejection}

The second advantage is that personalised chimaera organs are likely to cause no immune response, as they will be created from the recipient's own DNA. This means that recipients should no longer have to take immunosuppressant drugs for the rest of their lives, and will be spared any of the side effects (and the associated financial costs) of these medications. Therefore, chimaera organs could provide an increase in the quantity, and in the quality of organs.

Organs created using the intended recipient's DNA are likely to be expensive to produce, and it is possible that allogenic organs derived from human leukocyte antigen-matched iPSC cell lines will also be used. It is possible that a 'two-tier' system of chimaera organ provision could develop, with richer countries and patients being able to afford autologous organs, and less well-off nations and patients receiving inferior allogenic organs. The equity issues this would raise are beyond the scope of this paper. However, it should be noted that although the risk of rejection of such allogenic therapies would be higher than in personalised autologous therapies, they are still potentially lower than is currently the case for many organ recipients who must take whichever organ is available at any given time. Moreover, autologous therapies may prove to be cheaper in the long term despite higher initial costs, as they would avoid the need for ongoing costs such as immunosuppressant drugs and repeated transplantations.

\section{Box 1 Summary of the chimaera organ creation process}

1. Induced pluripotent stem cells generated from somatic cells taken from intended recipient

2. Human cells injected into pig embryo

3. Embryo implanted in sow

4. Gestation, birth, rearing of donor pig

5. Sacrifice of pig and transplantation of human organ into recipient

\section{ETHICAL CONCERNS ARISING FROM USE}

\section{OF CHIMAERA ORGANS}

\section{Risk of zoonosis}

Objections to xenotransplantation have focused on the potential risks of zoonosis: infection with a mutated animal virus that could then be passed on to other humans, possibly creating a pandemic. ${ }^{18}$ Zoonosis poses a public health threat to people other than the recipient, which as such has played a major role in halting xenotransplantation as a potential solution to the organ-scarcity problem.. However, compared with traditional xenotransplantation, organs obtained from chimaeras are likely to further reduce the already small risk of virus transfer, as the organ being transplanted would be human despite its 'gestation' inside an animal host. It is thought that precautionary monitoring of the donor-chimaeras during their development and testing of the organ prior to transplantation could all but eliminate the risk of accidental transplantation of contaminated organs. However, even if the risk of zoonoses arising from chimaera organs is almost zero, we must also consider the magnitude of any harm that might result. ${ }^{19}$ A deadly zoonosis could theoretically kill millions of people, and one might question whether the benefits of creating a new source of organs is worth outweighing the potential harms flowing from even a small risk of zoonosis. Should it be concluded that the zoonosis risk is not prohibitive, any chimaera organ programme should be subject to strict conditions including a very close monitoring to assess any ongoing threat of zoonosis.

A related concern is the generation of cancer, rather than viruses, in recipients of chimaera organs. The use of direct stem cell transplants has caused cancer in some patients. However, the use of a patient's own stem cells to create a replacement organ in an animal is unlikely to have this effect for two reasons: it is not a direct transplant of cells into the patient, and the cells involved will be heavily programmed towards specific purposes, unlike the cells in traditional stem cell transplants. Nonetheless, this is one other uncertainty that affects the potential use of chimaera organs.

\section{The human features problem}

While chimaera-sourced organs offer prospective advantages, the process of creating them raises another ethically relevant issue. Injecting human PSCs into animal embryos could theoretically risk the resulting animal itself developing human physical or mental features such as human limb development or neuronal development. Fortunately, the chances of this happening are remote. Even if human neurons were present in a pig brain, it is likely that they would act like pig neurons, being influenced by their environment rather than their genomic makeup. ${ }^{16}$ Furthermore, if any pig were found to have human gametes, it could simply be prevented from reproducing. It should be relatively simple to reduce these risks further still by knocking out genes for neuronal and gamete development in the human PSCs that are to be injected into the animal. Furthermore, the human features problem is not unique to the creation of chimaera organs, and has been raised before with regard to transgenic animals; in these earlier debates, the risks of development of human features were not judged sufficient to prevent use of the new biotechnology. ${ }^{20}$ Although creating chimaera organs might pose slightly different risks because of the different method used to introduce human material to the animal, there is no reason to assume that the risks of human features developing will be any higher. 


\section{Animal welfare}

The most obvious ethical objection to this means of producing organs is that (at least) one animal will be sacrificed for every human saved. This means that hundreds of thousands of animals will be killed each year in order to produce organs for humans if the technology is perfected. One possible response to this argument is that it seems strange to object to using pigs to save people's lives when it is generally regarded as acceptable to eat them. Eating meat is not necessary for survival, while working organs are: as such, it actually seems more reasonable for pigs to be used to grow life-saving organs than to provide the luxury of meat. However, any such argument is predicated on the assumption that it is ethical to eat animals in the first place. This assumption still persists all over the world, but may well be mistaken; given current prevalent attitudes, however, creating chimaera organs seems no worse than killing animals in order to eat them. It could also be objected that it is unfair to kill animals for their organs when many humans refuse to donate their organs after death. This is a valid point, but there would still be an organ scarcity problem even if all humans were willing to donate their organs after death, as most do not die in a way that makes organ donation possible. Furthermore, chimaera organs could ironically be a better medical solution than traditional transplants, due to the problem of immune rejection of organs from other humans.

Another potential objection is that pigs can be farmed in an ethical way, enjoying relatively happy lives before being used to produce meat, while chimaera animals would have relatively short lives in order to meet the supply for organs and would also have to be kept in very sterile conditions, with potential adverse effects on their well-being. There is also a possibility that genetically modified animals might suffer more than 'normal' animals, particularly if the developing human organ caused them discomfort. For example, the rat pancreas grown in the rat-mouse chimaeras maintained blood glucose levels at rat physiological levels, demonstrating that species-specific organ physiological parameters can dominate the entire organism. Nonetheless, given that society generally accords humans greater importance than animals, it appears that creating organs in this way would not threaten animal welfare in a new or unique way.

Finally, it should also be remembered that hundreds or perhaps thousands of animals will also need to be sacrificed as part of ongoing research into chimaera organs. While this is not very many in comparison with the number that will be sacrificed if the technique becomes widely used in humans, it should still be asked whether it is legitimate to use animals for this type of research. At first glance it might appear obvious that using them for research into a technology that could save dozens of human lives every day is more ethical than using them for research into a faint chance that a new drug might help a few dozen patients per year. However, there are two rebuttals to this point. First, the many uncertainties surrounding the creation of chimaera organs means that success is no more guaranteed than in any other animal research. Second, it could be argued that it is not in animals' interests to contribute to the perfection of chimaera organ biotechnology, and that it is actually against the interests of future animals. In normal medical research on animals, no more animals are used for testing or killed once the drug reaches the stage of clinical trials. In the case of chimaera organs, however, the success of clinical trials would mean that thousands more animals will be killed every year as part of the organ production process. In terms of animal solidarity, chimaera organ research is therefore worse than most medical research involving animals. However, from the human perspective, this type of research meets the requirements of proportionality and subsidiarity much more easily than most animal research, though other potential sources of organs (see table 1) should also be pursued. Given the possibility that these other avenues might not be successful, it would be irresponsible to discontinue current funding for chimaera organ research. (If a stricter definition of subsidiarity were adopted, it might be concluded that chimaera organ research should only continue if all other options have already been tried. However, we regard it as reasonable to adopt a more lenient definition that favours simultaneous pursuit of different organ sources.)

\section{Human dignity}

Finally, is human dignity threatened simply by the very creation of human/animal chimaeras? As is often the case when the concept of dignity is put to use in bioethics, it depends very much on what is meant by human dignity: while some will argue that it is against human dignity to let people die when we could save them with chimaera organs, it has also been suggested that the creation of chimaeras could threaten human dignity by mixing our basic constituents with those of animals. ${ }^{21}$ Similar arguments have previously been found to be flawed, ${ }^{20}$ for a variety of reasons. Human dignity was raised as a concern in 2007 in response to the creation of human/rabbit chimaera embryos, even though any such embryos were to be destroyed within 14 days of creation and had only $0.04 \%$ animal DNA. ${ }^{22}$ It has been claimed that "to produce creatures that blur the boundaries between humans and animals could threaten to undermine the concept of human dignity since it is a dignity specifically reserved to humankind". ${ }^{23}$ This argument appears to be camouflage for concerns about 'playing God' or the feelings of revulsion that the idea of chimaeras induces in many people. Just as revulsion does not constitute a sound reason for objecting to something, human dignity does not appear to be threatened merely by the act of creating human organs inside animals. Similarly, we cannot infer any ethical judgment from the fact that we would be 'crossing species boundaries'; doing so might be unnatural, but so is much of human endeavour. It is important to make the distinction between human dignity arguments based on the mere fact of mixing between species, and dignity arguments based on the potentially unethical consequences of creating chimaeras. While an animal with human mental features might seem a threat to human dignity, the precautions taken to prevent human neuronal (or reproductive) development should minimise the risk of this happening. In the absence of any adverse consequences, objections based on human dignity are deprived of most of their force. As the Academy of Medical Sciences has stated:

It has long been accepted that the dignity of man does not rule out many ways in which animal and human materials are combined....humans are not demeaned by the incorporation of parts of non-human animals (such as heart valves from pigs) through xenotransplantation, though it is possible to object to this practice on other grounds. Similarly, therefore, the creation by another form of xenotransplantation of animals which include significant human elements cannot be held to threaten human dignity just because it humanises the animals involved. ${ }^{21}$

Of course, anyone who did think that it violated human dignity to accept an organ that had been grown in an animal (or who had concerns about animal welfare) could simply refuse to accept one, although it may well be the case that weakly felt symbolic concerns about dignity might be abandoned if no other organ could be found. (This is not to suggest that 
everyone would abandon all ethical concerns if faced with death, but rather that many people's concerns about human dignity appear rather ephemeral, and that they might evaporate entirely or be refocused into concerns about the indignity of dying in the face of certain death.) Perhaps the most persuasive argument concerning human dignity is actually not that the proposed technology reduces us to mix our DNA with theirs, but that it is undignified for higher animals such as humans to instrumentalise and kill lesser animals in this way when there are other potential sources of organs. This is really an argument about animal welfare rephrased as one concerning human dignity. However, as already mentioned, all countries currently instrumentalise animals routinely, and using them to save lives may be ethically preferable to using them for non-essential purposes.

\section{CONCLUSION}

We have explored the potential harms and benefit of creating chimaera organs and analysed the various ethical issues raised by this new biotechnology. Organs from chimaeras have the potential to solve the current organ scarcity problem and save hundreds of thousands of lives each year, and to provide a limitless supply of organs that will not trigger any immune reaction. This new type of regenerative medicine therefore has the potential to provide organs to those on the waiting list, and to provide better organs to those who have already received an organ. However, more research is required in order to clarify several uncertainties about viability and safety, and several concerns remain regarding the human features problem, animal welfare and human dignity. These ethical issues must be debated and addressed before such organs are created; doing so will require significant engagement with the public. Finally, the inevitable violation of animal welfare entails that creating chimaera organs for transplantation would only be acceptable if no alternative solutions to the organ scarcity problem are found; research into finding such solutions will therefore remain necessary.

Contributors DS, WD and GdW are ethicists in the Department of Health, Ethics and Society at the University of Maastricht; DS also works at the Institute for Biomedical Ethics at the University of Basel. NG is a Professor of Regenerative Medicine at the Hubrecht Institute, University Medical Center Utrecht and Utrecht University Faculty of Veterinary Medicine. This paper arose from the authors' work on the Chimera Seeding Project, which was funded by the Dutch Centre for Society and the Life Sciences (CSG). DS wrote the first draft following discussion with all authors, and all authors contributed to revising and approving the final version. DS is the guarantor.

Competing interests None.
Provenance and peer review Not commissioned; externally peer reviewed.

\section{REFERENCES}

1 Organ Donation. UK: NHS Blood and Transplant. http://www.organdonation.nhs.uk/ (accessed 6 May 13).

2 British Medical Association. Building on progress: Where next for organ donation policy in the UK? London: BMA, 2012. http://bma.org.uk/working-for-change/ improving-and-protecting-health/organ-donation (accessed 6 May 13).

3 Takahashi K, Yamanaka, S. Induction of pluripotent stem cells from mouse embryonic and adult fibroblast cultures by defined factors. Cell 2006;126:663-76.

4 Okita K, Ichisaka T, Yamanaka S. Generation of germline-competent induced pluripotent stem cells. Nature 2007:448:313-17.

5 Takahashi K, Okita K, Nakagawa M. et al. Induction of pluripotent stem cells from fibroblast cultures. Nat Protoc 2007;2:3081-9.

6 Cyranoski D. Stem cells cruise to clinic. Nature 2013;494:413.

7 Fox C. Historic Japan Stem Cell Trial Approved. Bioscience Technology, 14 Aug 2013. http://www.biosciencetechnology.com/articles/2013/08/historic-japanstem-cell-trial-approved\#.UrQfgGQXRhQ

8 Takayama N, Eto K. Pluripotent stem cells reveal the developmental biology of human megakaryocytes and provide a source of platelets for clinical application. Cell Mol Life Sci 2012;69:3419-28.

9 Takayama N, Eto K. In vitro generation of megakaryocytes and platelets from human embryonic stem cells and induced pluripotent stem cells. Methods $\mathrm{Mol}$ Biol 2012;788:205-17.

10 Takayama N, Nishimura S, Nakamura S. et al. Transient activation of c-MYC expression is critical for efficient platelet generation from human induced pluripotent stem cells. J Exp Med 2010;207:2817-30.

11 Kobayashi T, Yamaguchi T, Hamanaka S. et al. Generation of rat pancreas in mouse by interspecific blastocyst injection of pluripotent stem cells. Cell 2010;142:787-99.

12 Isotani $A$, Hatayama $H$, Kaseda $K$, et al. Formation of a thymus from rat ES cells in xenogeneic nude mouse<-->rat ES chimeras. Genes Cells 2011;16:397-405.

13 Rossant J, Croy BA, Chapman VM, et al. Interspecific chimeras in mammals: a new experimental system. J Anim Sci 1982;55:1241-8.

14 Matsunari $H$, Nagashima H, Watanabe M, et al. Blastocyst complementation generates exogenic pancreas in vivo in apancreatic cloned pigs. Proc Natl Acad Sci USA 2013;110:4557-62.

15 Proceedings of the International Conference on Chimera Organs. Utrecht, 4.12.13.

16 Gafni 0 , Weinberger $L$, Mansour AA, et al. Derivation of novel human ground state naive pluripotent stem cells. Nature 2013;504(7479):282-6.

17 Shaw D, Dondorp W, de Wert G. Using Non-Human Primates to benefit humans: Research and Organ Transplantation. Med Health Care Philos 2014;17:573-8.

18 Patience C, Takeuchi Y, Weiss RA. Zoonosis in xenotransplantation. Curr Opin Immunol 1998;10(5):539-42.

19 McLean S, Williamson L. The demise of UKXIRA and the regulation of solid-organ xenotransplantation in the UK. J Med Ethics 2007;33(7):373-5.

20 Robert JS, Baylis F. Crossing species boundaries. Am J Bioeth 2003;3(3):1-13.

21 Academy of Medical Sciences. Animals containing human material. 2011. http://www.acmedsci.ac.uk/p47prid77.html\#downloads (accessed 6/5/13).

22 Chimeras are a shocking affront to human dignity. Catholic Herald, 14 Sep 2007. http://archive.catholicherald.co.uk/article/14th-september-2007/11/ chimeras-are-a-shocking-affront-to-human-dignity (accessed 6 May 13)

23 MacKellar C. File 34: Chimeras, hybrids and 'cybrids'. Christian Medical Fellowship, 2007. http://admin.cmf.org.uk/pdf/cmffiles/34_hybrids.pdf (accessed 6 May 13) 